\begin{tabular}{|l|l|l||}
\hline \multicolumn{2}{|c|}{ PublisherInfo } \\
\hline \hline PublisherName & $:$ & BioMed Central \\
\hline \hline PublisherLocation & $:$ & London \\
\hline \hline PublisherImprintName & $:$ & BioMed Central \\
\hline \hline
\end{tabular}

\title{
Old flies
}

\begin{tabular}{|l|c|l||}
\hline \multicolumn{2}{|c|}{ ArticleInfo } \\
\hline \hline ArticleID & $:$ & 4650 \\
\hline \hline ArticleDOI & $:$ & $10.1186 /$ gb-spotlight-20021204-01 \\
\hline \hline ArticleCitationID & $:$ & spotlight-20021204-01 \\
\hline \hline ArticleSequenceNumber & $:$ & 316 \\
\hline \hline ArticleCategory & $:$ & Research news \\
\hline ArticleFirstPage & $:$ & 1 \\
\hline \hline ArticleLastPage & $:$ & 2 \\
\hline \hline & & RegistrationDate : 2002-12-4 \\
\hline ArticleHistory & $:$ & OnlineDate \\
\hline \hline ArticleCopyright & $:$ & BioMed Central Ltd2002-12-4 \\
\hline \hline ArticleGrants & $:$ & \\
\hline \hline ArticleContext & $:$ & 130593311 \\
\hline \hline
\end{tabular}




\section{Jonathan B Weitzman}

Email: jonathanweitzman@hotmail.com

Studies of aging in a number of model organisms have provided insights into the mysteries of longevity. In the November 29 Science Rogina et al. add another piece to the aging puzzle, by investigating the relationship between histone deacetylases, caloric restriction, and longevity in Drosophila (Science 2002, 298:1745). Flies that are heterozygous for a null or hypomorphic mutation in the gene encoding the Rpd3 deacetylase live longer than wild-type controls. The increased lifespan is equivalent to that seen in flies on a low-calorie diet. But the two effects are not additive, suggesting that they are on the same pathway. Both life-expanding treatments (diet or Rpd3 mutation) are associated with an increase in the levels of the Sir2 deacetylase, a protein linked to life-span in yeast.

\section{References}

1. Model organisms as a guide to mammalian aging.

2. Science, [http://www.sciencemag.org] 